\title{
PERANCANGAN MAJALAH DIGITAL CANDI-CANDI DI MALANG RAYA BERBASIS INFOGRAFIS
}

\author{
Rahmat Kurniawan, Saiful Yahya \\ Sekolah Tinggi Informatika dan Komputer Indonesia Malang
}

\begin{abstract}
Penelitian ini bertujuan untuk merancang infografis tentang beberapa candi di wilayah Malang berbasis digital berupa majalah infografis. Terdapat lima candi yang menjadi objek perancangan infografis meliputi; candi Singasari, candi Jago, candi Kidal, candi Badut dan candi Sumberawan. Variabel penelitian yang akan disajikan dalam infografis meliputi aspek Sejarah, Bentuk atau struktur, makna, dan fungsi pada candi. Metode perancangan majalah infografis meliputi 1) identifikasi permasalahan; 2) Pengumpulan data; 3) Analisa data; 4) Perancangan infografis; 7) Desain final. Pengumpulan data meliputi data pustaka dan data lapangan. Dalam proses perancangan meliputi dua aspek meliputi konsep perancangan dan desain visual. Sumber data yang akan digunakan dalam perancangan ini meliputi 1) data primer yang diperoleh dari hasil observasi, dokumentasi, dan wawancara dengan pakar sejarah atau informan yang memahami sejarah candi yang diteliti, dan 2) data sekunder yang diperoleh melalui literasi yang menunjang terkait candi yang diteliti. Hasil perancangan berupa informasi tentang intrepretasi berdasarkan sejarah, bentuk atau struktur, makna dan fungsi pada lima bangunan candi. dari hasil analisis dapat disimpulkan bahwa bangunan candi yang dianalisis merupakan peninggalan kerajaan Singasari. Selain itu candi dibangun pada masa dimana agama hindu menjadi agama yang dianut pada masa itu hal ini bisa dilihat dari bentuk candi dan cerita relief yang terdapat pada candi.
\end{abstract}

Keywords: Infografis, Majalah, Candi, Malang

\begin{abstract}
This research aims to design infographics about several temples in Malang based on digital based in the form of infographic magazines. There are five temples that are objects of infographic design including; Singasari temple, Jago temple, Kidal temple, Badut temple and Sumberawan temple. Research variables that will be presented in infographics include aspects. History, form or structure, meaning, and function of the temple. The infographic magazine design methods include 1) identification of problems; 2) data collection; 3) Data analysis; 4) infographic design; 7) Final design. Data collection includes library data and field data. In the design process includes two aspects including the concept of design and visual design. Data sources that will be used in this design include 1) primary data obtained from observations, documentation, and interviews with historical experts or informants who understand the history of the temple under study, and 2) secondary data obtained through supporting literacy related to the temple being studied. The results of the design in the form of information about interpretation based on history, form or structure, meaning and function in five temple buildings. From the analysis it can be concluded that the temple building analyzed is a relic of the Singasari kingdom. In addition, the temple was built at a time when Hinduism became a religion that was embraced at that time this can be seen from the shape of the temple and relief stories contained in the temple.
\end{abstract}

Keywords: Infographics, Magazines, Temples, Malang

Correspondence author: Rahmat Kurniawan, Rahmat@stiki.ac.id, Malang, Indonesia 


\section{Pendahuluan}

Candi merupakan salah satu peninggalan sejarah yang punya peranan penting dalam sejarah perkembangan kebudayaan di Indonesia. Lebih dari seratus candi tersebar di seluruh penjuru negeri dari Sabang sampai Merauke. Penyebaran candi terbanyak antara lain di pulau jawa. Hal ini dilatar belakangi oleh banyaknya kerajaan kerajaan yang menganut agama Hindu dan Budha. Sebelum Islam masuk ke Nusantara, agama Hindu-Budha lebih dulu tumbuh dan berkembang pesat di wilayah ini sejak era kerajaan Mataram lama sampai era Majapahit. Candi menjadi salah satu tempat untuk melakukan berbagai acara keagamaan waktu itu.

Di jaman sekarang ini keberadaaan candi-candi di Indonesia telah menjadi salah sektor wisata unggulan masing masing daerah. Di pulau Jawa Salah satu wilayah yang cukup banyak penyebarannya yakni di Jawa Timur tepatnya di kabupaten Malang. Kabupaten Malang merupakan wilayah yang mempunyai perjalanan sejarah yang cukup penting dalam perkembangan peradaban di Indonesia. Wilayah ini merupakan tempat berdirinya kerajaan Singasari memiliki situs candi yang cukup banyak. Lebih dari 10 candi yang saat ini menjadi objek wisata.

Keberadaan candi sebagai objek wisata di kota Malang saat ini tidak seperti tempat wisata lainnya. Candi sebagai tempat wisata kenyataannya kurang diminati oleh masyarakat khususnya generasi muda. Banyaknya objek wisata alam dan wisata wahana menjadi destinasi utama para wisatawan. Kondisi ini membuat objek wisata budaya semakin tenggelam. Selain itu, keberadaan objek wisata seperti candi saat ini hanya disadari sebagai tempat hiburan semata. lebih dari itu keberadaan candi menjadi salah satu objek kajian sejarah. Banyak nilai-nilai sejarah yang dapat dipelajari melalui relief-relief yang tergambar di setiap dinding-dinding candi. Mengutip pernyataan pakar desain Sumbo Tinarbuko tentang bagaimana sebuah desain komunikasi visual menjadi sebuah penanda zaman. Menurut Tinarbuko desain merupakan representasi sosial dan budaya masyarakat, dan nilai-nilai yang berlaku pada waktu tertentu. Keberadaan relief-relief pada candi ini dipandang sebagai salah bentuk komunikasi visual yang menjadi sarana dalam mengkaji perkembangan sejarah tentang peran candi sekaligus memahami kondisi sosial dan budaya saat itu. Hal ini tentu menjadi sangat menarik untuk diperkenalkan kepada wisatawan atau masyarakat pada umumnya. Namun saat ini sarana pengenalan sejarah tentang bagaimana memahami candi keberadaannya masih terbatas.

Media infografis sebagai salah satu media komunikasi dan informasi secara detail dan sistematis diharapkan bisa menjadi strategi yang efektif dalam memahami struktur, makna fungsi sebuah candi-candi yang ada di Malang. Pentingnya media informasi berbasis infografis tentang candi bisa menambah wawasan masyarakat tentang kearifan lokal dan diharapkan mampu menumbuhkan sikap peduli terhadap kekayaan budaya Indonesia. Oleh karena itu perancangan infografis ini perlu dilakukan sebagai upaya menghidupkan kembali objek wisata berbasis budaya di Malang. Target audiens dalam perancangan ini adalah remaja yang dalam kesehariannya tidak lepas dari gadget. Oleh karena itu perancangan ini akan dibuat sekumpulan infografis akan dikemas dalam bentuk majalah digital agar mudah untuk diakses melalui gadget atau perangkat elektronik lainnya.

Tujuan dalam perancangan ini adalah untuk mengetahui proses merancang majalah digital infografis tentang candi-candi di wilayah Malang. Adapun manfaat yang diharapkan dari penelitian ini antara lain Menambah wawasan tentang keberadaan candi-candi di Malang sekaligus menjadi kekayaan budaya Malang Raya. Memberikan pemahaman tentang candi yang bukan hanya sebagai objek wisata melainkan sebagai objek karya seni bernilai tinggi. Memberikan pemahaman bagaimana cara membaca struktur, makna dan fungsi pada candi. 


\section{Metode}

Metode perancangan dalam majalah infografis candi ini meggunakan model dari Sanyoto yang diadaptasi sesuai kebutuhan. Model tersebut terdiri 1). Latar belakang 2). Identifikasi data. 3) Analisis data yang meliputi data pustaka dan data lapangan. 4) Proses perancangan yang meliputi konsep perancangan dan desain visual dan 5) desain final. Sumber data yang digunakan dalam penelitian ini adalah data primer yang diperoleh dengan cara observasi langsung di lapangan. Sedangkan data sekunder diperoleh dengan cara studi literasi dari berbagai sumber terkait. Variabel yang diteliti dalam perancangan ini antara lain; aspek sejarah, aspek bentuk, aspek makna, dan aspek fungsi. Data dalam proses perancangan ini diperoleh menggunakan dua instrumen. Instrumen pertama adalah wawancara dengan narasumber yang memahami sejarah serta seluk beluk candi yang diteliti. Instrumen kedua yakni observasi terhadap sumber-sumber visual dengan cara mendokumentasi menggunakan media rekam. Data yang didapat kemudian di analisis dengan cara mereduksi data sesuai kebutuhan. Hasil reduksi data diintrepretasi kemudian disajikan dalam bentuk narasi dan bahasa visual berupa bentuk-bentuk ikonografis.

\section{Hasil dan Pembahasan}

Menurut Kamus Besar Bahasa Indonesia, istilah candi dapat diartikan sebagai banguna yang terbuat dari Batu. Sedangkan menurut Soekmono candi merupakan bangunan-bangunan jaman purba yang terbuat dari batu yang disusun yang sampai saat ini keberadaannya masih ada dan sampai ke kita. Bangunan tersebut disucikan karena sangat erat dengan kegiatan spiritual. Jadi dapat disimpulkan bahwa candi merupakan bangunan yang terbuat dari susunan batu yang dibuat untuk kepentingan kegiatan keagamaan. Umumnya Candi-candi tersebut merupakan peninggalan kerajaan Hindu dan Budha di masa lampau. keberadaan candi di seluruh penjuru negeri menjadi bukti bagaimana kebudayaan Hindu dan Budha telah pernah mencapai puncak peradaban sebelum akhirnya islam masuk ke Nusantara.

Kota Malang merupakan kota terbesar kedua di Jawa timur yang kaya akan objek wisata. Salah satu wisata yang terkenal di Malang adalah wisata sejarah dimana wisata tersebut berupa peninggalan sejarah dalam bentuk fisik, yakni bangunan candi. Candi merupakan bangunan atau monumen yang tersusun oleh kumpulan batu-batu yang berfungsi sebagai makam atau acara keagamaan. sekaligus menjadi cagar budaya. Candi-candi tersebut merupakan situs peninggalan kerajaan Singasari yang tersebar di beberapa lokasi. Kondisi bangunan candi-candi tersebut ada yang sudah utuh dan ada juga yang sudah mengalami pemugaran. Dilansir dari Primadia, setidaknya ada sekitar 13 candi yang sudah dikenal dan terdaftar sebagai situs peninggalan kerajaan singasari. Candi -candi tersebut antara lain: 1). Candi kidal di kecamatan Tumpang; 2) Candi Singosari di kecamatan Singosari; 3) Candi Jago di kecamatan Tumpang; 4) Candi Sumberawan di kecamatan Singosari 5) Candi gunung Arjuna di kecamatan Lawang; 6) Candi Jawar Ombo di kecamatan Ampelgading; 7) Candi Bocok di kecamatan Kasembon; 8) Candi Telih di kecamatan Karang ploso; 9) Candi Badut di kecamatan Tidar; 10) Candi Songgoriti di Batu; 11) Candi Selakelir di lereng gunung penanggungan; 12) Candi Karangbesuki di kecamatan Sukun

Dari sekian banyak candi yang telah disebutkan di atas, hanya sekitar 5 candi yang akan dibuat dalam bentuk infografis. Pemilihan candi-candi tersebut didasarkan atas pertimbangan jumlah data yang bisa diambil serta kondisi bangunan, sedangkan pertimbangan lain adalah 
waktu, biaya dan akses menuju lokasi. Candi yang akan diobservasi adalah candi masih memungkinkan untuk dilakukan penggalian data secara struktur visual, makna dan fungsi.

Infografis berasal dari kata Infographics dalam Bahasa Inggris yang merupakan singkatan dari Information + Graphics adalah bentuk visualisasi data yang menyampaikan informasi kompleks kepada pembaca agar dapat dipahami dengan lebih mudah dan cepat (Lankow et al.). Infografis dapat disebut juga sebagai ilustrasi informasi (Glasgow and Elasky). Proses pembuatan infografis disebut data-visualization, information design, atau information architecture.

Infografis memiliki banyak keunggulan di antara mampu menyajikan data dengan cukup lengkap dan sistematis menggunakan bentuk bentuk visual yang mudah dipahami. Perpaduan antara gambar dan tulisan yang efektif dalam infografis dapat mempengaruhi berbagai aspek pada pembaca. Menurut Lankow et al. ada tiga ketentuan dasar utama dalam membangun komunikasi melalui infografis meliputi: 1). Daya pikat. Komunikasi harus terjalin dengan audiens secara sukarela; 2) Komprehensi. Komunikasi harus dengan efektif meyediakan pengetahuan yang memungkinkan pemahaman yang jelas atas informasi; 3 ) Retensi. Komunikasi harus tidak mudah dilupakan. Beragamnya perkembangan dan bentuk informasi memengaruhi atensi audiens dalam menyerap informasi. Hal ini sejalan dengan pendapat Resnatika et al. yang menyatakan jika ketika sebuah informasi akan mudah dipahami dan dapat menjadi pengetahuan dan informasi yang baru bagi audies apabila dikemas dalam bentuk yang lebih menarik dan tidak membosankan. Infografis dianggap mampu menyampaikan informasi secara detail dan akurat. Ditambah lagi visualisasi yang menarik, tentunya akan membuat media informasi jenis ini dianggap lebih efektif dan efisien. Hal ini dapat membantu perancangan yang dilakukan untuk menyajikan data-data visual tentang candi.

\section{Identifikasi Data}

Dari hasil identifikasi maka ditemukan beberapa fakta bahwa Malang sebagai kota yang kaya akan objek wisata, salah satu objek wisata yang bisa dikunjungi adalah objek wisata candi. berbeda dengan objek wisata pada umumnya, wisata budaya candi ini menjadi menarik untuk dikaji mengingat bangunan candi merupakan bangunan yang kaya akan nilai budaya dan religi. Setiap bagian pada candi memiliki makna dan sejumlah informasi yang menarik untuk dipahami. Selain itu, wawasan keilmuan tentang pembacaan candi menjadi penting untuk diketahui agar masyarakat mampu memahami latat belakang keberadaan bangunan candi sekaligus memahami kebudayaan masa lalu.

\section{Analisa Data}

Interpretasi

Konsep perancangan diawali dengan tahap menginterpretasi hasil temuan data dilapangan. Perlu dipahami bahwa efektivitas penyampaian informasi dalam infografis sangat tergantung pada bagaimana cara menginterpretasi dan visualisasi data. Hasil intrepretasi data adalah sebagai berikut :

1. Sejarah candi. Sejarah candi menjadi penting untuk dimunculkan untuk memberikan informasi secara umum seperti kapan, dimana dan oleh siapa candi tersebut dibangun. Hal ini juga terkait dengan terkait dengan kebudayaan yang melatar belakangi pembangunan candi. Berdasarkan hasil interpretasi dapat disimpulkan bahwa beberapa candi yang diteliti sebagian besar merupakan sisa peninggalan kerajaan singasari. Kerajaan Singasari adalah kerajaan yang sebagian wilayah kerajaannya merupakan wilayah Malang dimana pusat pemerintahannya berada di daerah Singasari yang kini menjadi salah satu nama kecamatan yang ada di Kabupatan Malang. 
2. Struktur Candi. Kajian struktur pada candi membahas mengenai bagaimana bentuk dan susunan bangunan pada candi. tujuan mengkaji struktur candi antara lain untuk mengetahui gaya desain arsitektur bangunan tersebut dan material yang digunakan. Selain itu, struktur dan gaya desain menjadi informasi mengenai latar belakang candi, apakah candi tersebut merupakan candi hindu atau candi budha. Berdasarkan hasil data di lapangan sebagian besar candi terindentifikasi merupakan candi peninggalan agama Hindu. Hal ini terlihat dari struktur candi yang sebagian bangunannya berbentuk kerucut. Berbeda dengan candi budha yang stuktur bangunannya lebih memiliki banyak stupa dengan ukuran besar dan bulat. Namun ada beberapa candi yang tergolong sebagai candi budha yakni candi sumber awan. Dimana terdapat stupa dibagian atas candi.

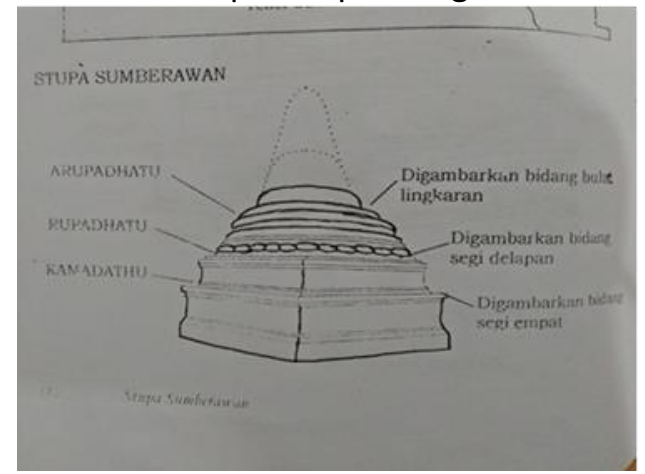

Gambar 1 Struktur asli candi sumberawan.

3. Fungsi candi. Semua bangunan candi pada awalnya memiliki fungsi yang sama dalam penciptaannya, yakni sebagai bangunan suci yang digunakan sebagai pemakaman atau upacara keagamaan. Ada juga beberapa candi yang dibangun sebagai bentuk persembahan kepada kerajaan atau sebagai bukti kekuasaan raja yang pada masa itu. Namun karena perkembangan zaman, fungsi tersebut perlahan bergeser menjadi fungsi yang lain. seperti yang terjadi pada candi Jago. Fungsi candi Jago pada era Singasari dan Majapahit sebagai tempat beribadah, dan sebagai tempat pendarmaan dan penyimpanan abu jenazah Raja Sri Jaya Wisnuwardhana, dalam hal ini candi bukan sebagai makam.

Sedangkan untuk fungsi di masa sekarang adalah sebagai tempat wisata, wisata ini dibagi menjadi dua, yaitu wisata religi bagi mereka pemeluk agama Hindu dan Budha untuk melakukan ibadah di candi tersebut, lalu yang kedua adalah sebagai destinasi wisata sejarah untuk umum. Menurut informan, banyak wisatawan domestik maupun wisatawan asing yang berkunjung ke situs sejarah tersebut. Pergeseran fungsi ini juga berpengaruh kepada sektor pariwisata dan perekonomian daerah setempat. Kehadiran candi sebagai destinasi wisata kini meningkatkan perekonomian masyarakat. Banyak masyarakat yang berjualan disekitar area wisata.

4. Makna visual candi. Kajian terhadap objek-objek visual dilakukan untuk menginterpretasi bentuk dan symbol visual yang terdapat pada candi. Bentuk-bentuk visual didapatkan dari beberapa dinding candi berupa relief yang menceritakan kitab suci atau kehidupan pada masa itu. Sejalan dengan ini Klokke menyebutkan bahwa secara garis besar relief pada sebuah percandian atau artefak lainnya dapat dibagi dua, yaitu relief naratif (bercerita) dan relief dekoratif (pengisi bidang). Relief naratif berwujuad rentetan objek visual yang berupa figur yang saling terkait satu sama lain sehingga membantu satu cerita yang utuh. Sedangkan relief dekoratif lebih kepada simbol-simbol visual juga berwujud ornamen-ornamen ukiran, arca maupun objek yang juga mengandung makna tertentu. 
Pada candi kidal terdapat beberapa relief yang mengisahkan cerita tentang riwayat Garudeya. Garudeya merupakan kesusastraan jawa berbentuk kakawin yang mengisahkan perjalanan garuda dalam mencari amerta untuk membebaskan ibunya dari perbudakan hingga pada akhirnya ia menjadi salah satu pengabdi Dewa Wisnu. Cerita ini dulu popular sebagai kisah yang mengandul pesan moral cukup mendalam. Cerita garudeya ini terpahat di setiap sisi candi kidal kecuali pada pintu masuk. Untuk membaca naskah relief ini harus berjalan berlawanan dengan arah jarum jam, atau yang lebih dikenal dengan istilah Prasawiya. Mulai dari sisi sebelah kanan tangga pintu masuk candi kemudian memutar dan berhenti pada sisi kiri.

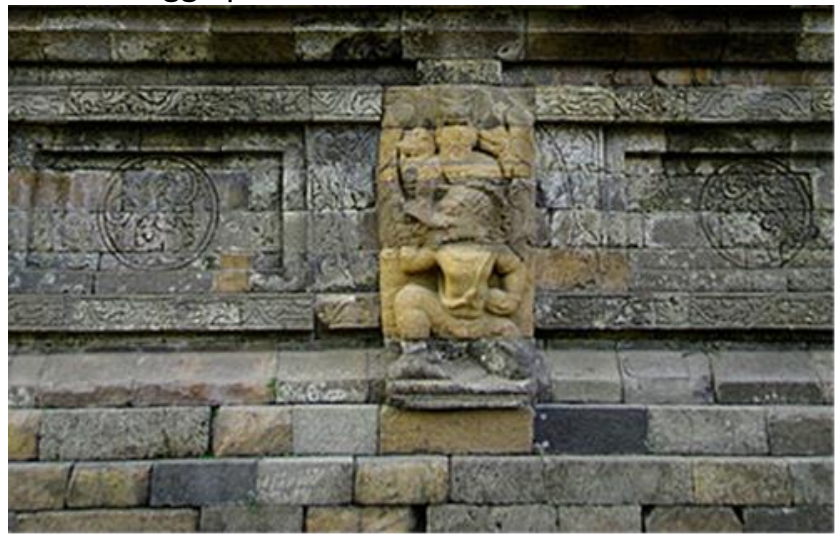

Gambar 2 Relief garuda saat menjalani perbudakan

Pada gambar di atas merupakan bagian awal yang menceritakan tentang garuda yang melayani 3 ular. Pada relief tersebut sosok garuda digambarkan dengan posisi duduk dengan salah satu kaki berlutut. Posisi ini memiliki makna sebagai bentuk pengabdian kepada 3 ular. Ketiga ular berada di atas kepala garuda yang menunjukkan bahwa ketiga ular tersebut dilayani oleh garuda. Pada gambar tersebut pakaian yang dikenakan garuda yaitu hanya menutupi bagian paha, sedangkan bagian atas tidak mengenakan apa-apa. Selain itu menggunakan beberapa aksesoris yang identik dengan kepercayaan dalam agama hindu. Gaya berpakaian ini banyak dijumpai pada cerita-cerita agama hindu. Berbeda dengan gaya berpakaian pada agama budha yang hanya menggunakan kain sederhana yang dililitkan dari pundak hingga menutupi bagian bawa tubuh. Relief ini menceritakan bagaimana sang garuda menjadi budak dari para ular atau naga karena kelicikan dari ibu para ular tersebut.

Selain relief garuda, terdapat ornament lain yang berada di atas pintu masuk candi. Ornamen tersebut berbentuk kepala Batarakal/raksasa. Patung kala ini merupakan simbol dari waktu atau alam semesta. Bentuk visual dari patung ini digambarkan berupa wajah seperti manusia namun memiliki mata yang besar dan taring. Di setiap sisi wajahnya terdapat beberapa ornament berupa hiasan dekoratif. Patung kala ini banyak terdapat diberbagai candi bercorak hindu. Salah satu candi yang juga memiliki patung kalah adalah seperti yang terdapat di candi Jago.

Beda halnya relief yang terdapat pada candi Jago, dimana relief ini memiliki cerita yang paling panjang dibanding candi yang ada di Jawa Timur. Ada sekitar 6 panel dimana tiap panel menceritakan kisah yang berbeda. Menurut Sama seperti candi kidal, pembacaan relief pada candi jago dibaca dengan cara berlawanan dengan arah jarum jam. Salah satu panel dalam candi Jago menceritakan tentang Kuntjarakarna atau surga dan neraka. Relief tersebut tergambar di bagian tingkatan dasar mengelilingi candi yang dipahat dengan ukuran kecil. 


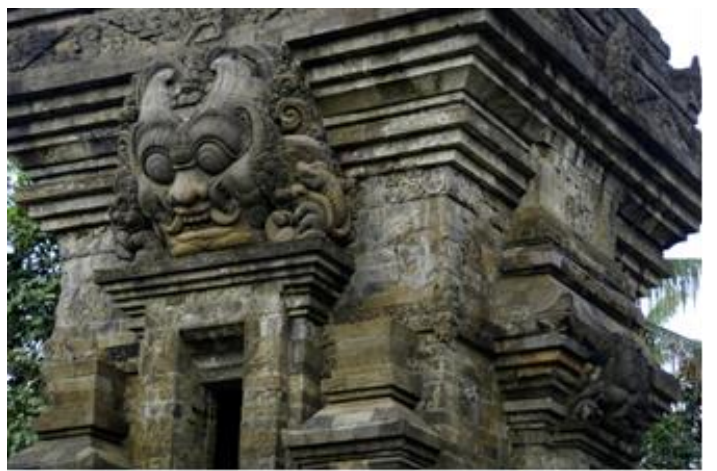

Gambar 4 Patung kala pada pintu masuk candi kidal dan candi Jago Kabupaten Malang

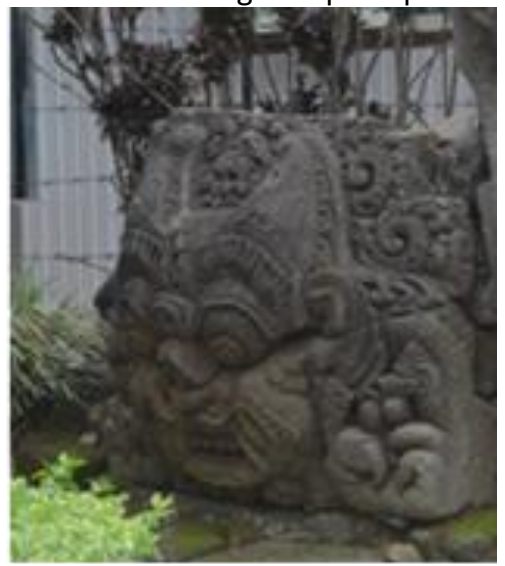

Gambar 5 Patung kala pada pintu candi Jago Kabupaten Malang

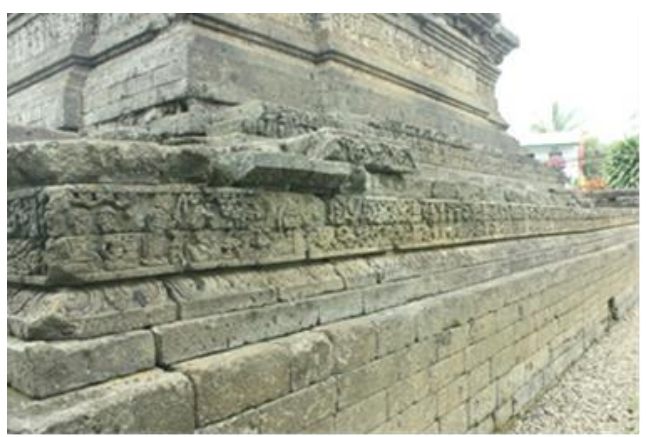

Gambar 6 Relief Kuntjarakarna pada Candi Jago

\section{Proses Perancangan}

Konsep perancangan

1. Alur cerita. Merancang alur cerita infografis harus berdasarkan tujuan. Ada 2 tujuan dalam penciptaan infografis meliputi 1). Infografis sebagai petunjuk/porsedur 2). Sebuah solusi permasalahan. Perancangan majalah infografis ini menggunakan alur cerita sebagai pemaparan solusi permasalahan berupa penyampaian informasi bagaimana cara memahami dan membaca objek visual pada bangunan candi.

2. Desain Layout. Terdapat banyak desain layout yang bias digunakan dalam memaparkan informasi, Antara lain : 1) Statistical; 2) Timeline; 3) Process; 4) Informational; 5) Geographic; 6) Comparison; 7) Hierarchical. 8). Chart-Centric. Berdasarakan tujuan perancangan maka desain layout yang digunakan dalam perancangan ini adalah berupa informasi. Perancangan infografis bertujuan untuk memberikan informasi mengenai sejarah candi, proses 
penciptaan candi, dan makna pada setiap bangunan candi. format infografis berorientasi portrait agar lebih bisa mengakomodasi bentuk bentuk visual dan meningkatkan keterbacaan pesan.

\section{Desain visual}

Objek visual merupakan elemen utama yang menjadi sumber informasi dalam infografis. Menurut Saptodewo, kata graphic dalam kata Infographic itu berarti visual, gambar, yang jika diterjemahkan dalam Bahasa Indonesia adalah grafis, bukan grafik. Sama seperti penulisan yang benar adalah desain grafis, bukan desain grafik. Meskipun secara pengertian grafik pun merupakan penyajian berbentuk gambar.

Dalam peracangan infografis candi ini data yang sudah diperolah kemudian diwujudkan ke dalam bahasa visual dan bentuk ikonografis. Proses visualisasi mengacu pada prinsip -prinsip desain meliputi keseimbangan, keharmonisan, ruang kosong, dan irama. Ikon yang digunakan diantaranya titik lokasi, kaca pembesar, label, titik/spot.

Tabel 1 penggunaan ikon

\begin{tabular}{ll}
\hline No Ikon & $\begin{array}{l}\text { Makna } \\
\text { lokasi wilayah candi }\end{array}$ \\
\hline 1 & $\begin{array}{l}\text { Menjelaskan sejarah } \\
\text { dan kapan ditemukan } \\
\text { candi }\end{array}$ \\
\hline 3 & $\begin{array}{l}\text { Menjelaskan nilai atau } \\
\text { makna visual dalam } \\
\text { setiap intepretasi }\end{array}$ \\
\hline 4 &
\end{tabular}

Jenis font yang digunakan dalam perancangan lebih banyak menggunakan font bertipe sanserif. Pemilihan font didasarkan karena bentuk font lebih sederhana sehingga mampu meningkatkan keterbacaan. 


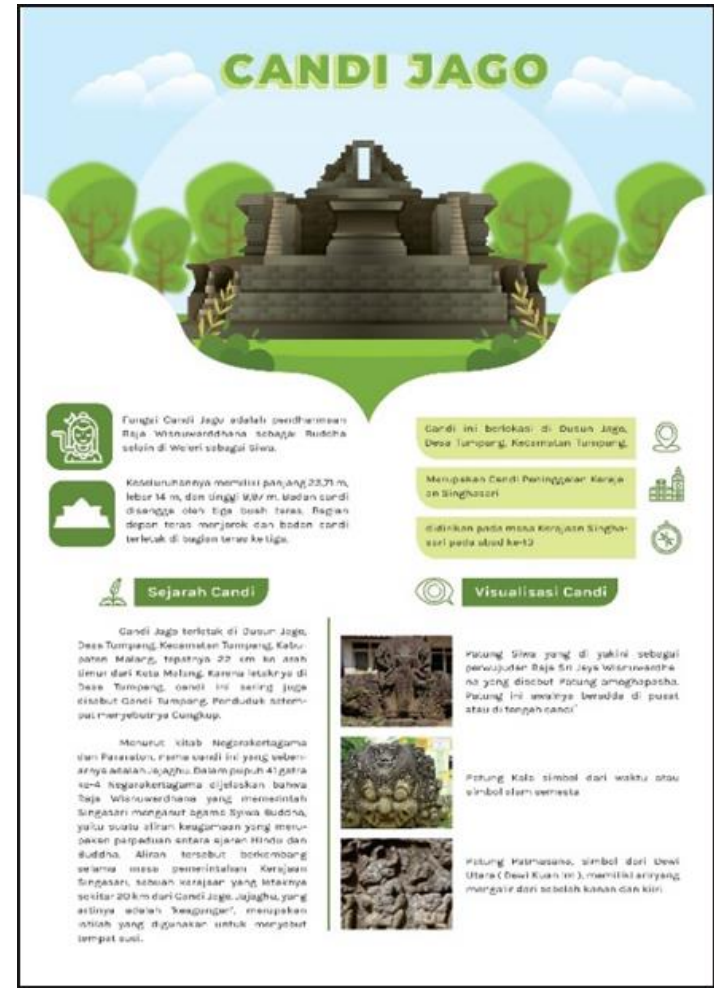

Gambar 7 infografis candi Jago

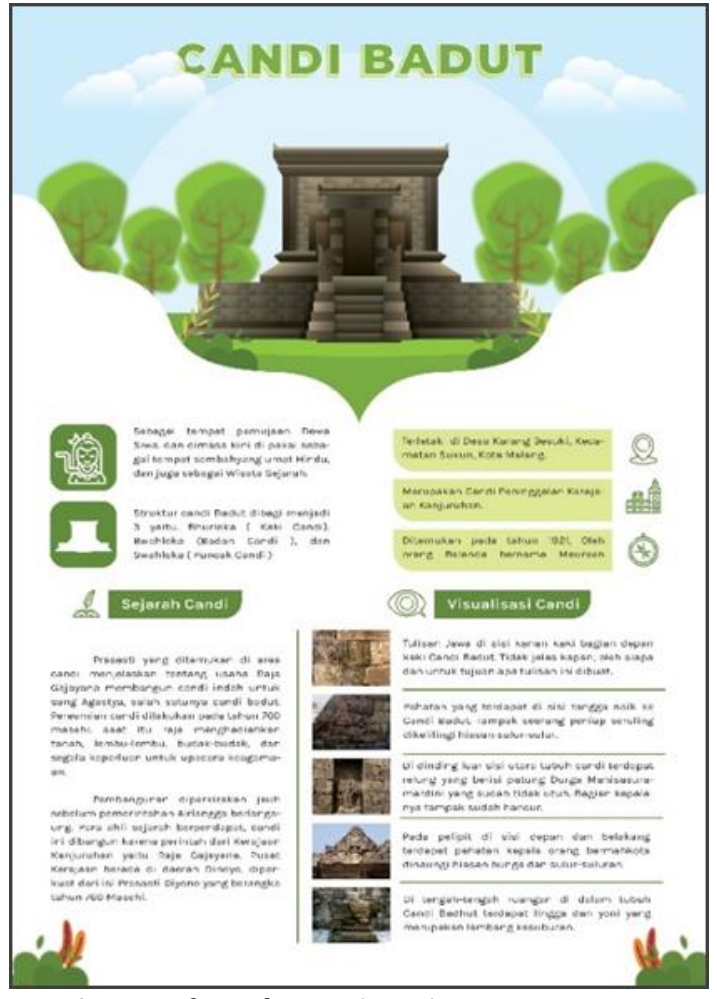

Gambar 8 infografis candi Badut

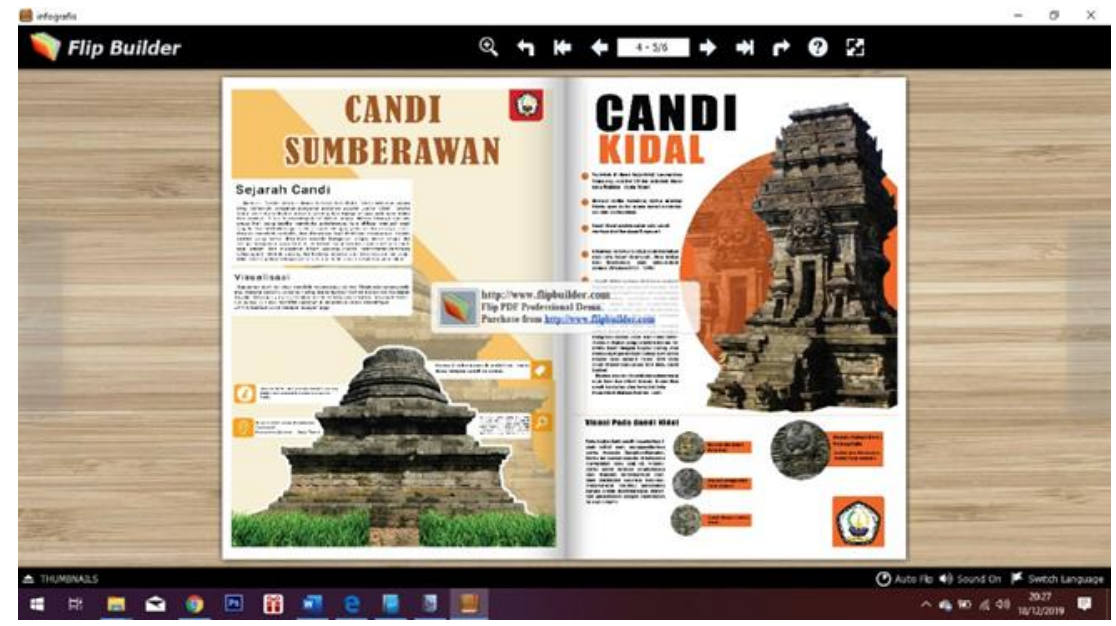

Gambar 9 Hasil Flipbook majalah infografis

\section{Simpulan}

Kota Malang yang dulunya merupakan wilayah salah satu kerajaan terbesar di Jawa, kini memiliki banyak peninggalan-peninggalan penting berupa candi yang tersebar di seluruh Malang Raya. Candi sebagai bangunan suci peninggalan prasejarah mempunyai makna penting dalam kehidupan masyarakat. Selain berisi informasi tentang kebudayaan masa lalu, keberadaan artefak sejarah ini menjadi salah kekayaan budaya yang patut dilestarikan maupun 
dikembangkan. Struktur dan simbol-simbol yang terdapat pada bangunan candi yang kaya akan informasi menjadi penting untuk menggali latar belakang kebudayaan pada masa itu.

Dari 5 candi yang telah ditelusuri merupakan candi peninggalan kerajaan singasari yang berlatar belakang agama hindu. Hal ini bisa dilihat dari struktur candi Hindu yang memiliki ciri khas berbentuk kerucut dan ramping. Selain itu terdapat beberapa relief atau ornament visual yang memiliki kesamaan antara candi satu dengan yang lainnnya. 2 Dalam mengintrepretasi bangunan candi dibutuhkan sumber yang relevan baik sumber primer maupun sekunder (literasi) hal ini untuk memperkuat proses intpretasi agar menghasilkan temuan yang valid.

\section{Ucapan Terima kasih}

1. Terima kasih kepada LPPM Stiki Malang yang telah memberikan segala fasilitas dan bantuan demi tercapainya kegiatan penelitian

2. Terima kasih kepada tim peneliti atas kerja keras selama proses penelitian

\section{Daftar Pustaka}

Departemen Pendidikan dan Kebudayaan. "Kamus Besar Bahasa Indonesia". edited by Antom M. Moeliono, Balai Pustaka, 1988.

Glasgow, Dale and Dan Elasky. Information Illustration: Learn How to Create Imaginative Diagrams, Charts, Maps, and Symbols on the Computer. Addison-Wesley Longman Publishing Co., Inc., 1994.

Klokke, Marijke J. The Tantri Reliefs on Ancient Javanese Candi. vol. 153, KITLV Press, 1993.

Lankow, Jason et al. Infografis: Kedasyatan Cara Bercerita Visual. translated by Alex Tri Kantjono Widodo, Kompas Gramedia, 2014.

Primadia, Adara. "13 Candi Di Malang Jawa Timur Beserta Penjelasanya." SejarahLengkap.com https://sejarahlengkap.com/bangunan/candi-di-malang. Accessed 28 Mei 2019.

Resnatika, Ajeng et al. "Peran Infografis Sebagai Media Promosi Dalam Pemanfaatan Perpustakaan." Jurnal Kajian Informasi \& Perpustakaan, vol. 6, no. 2, 2018, pp. 183196, doi:https://doi.org/10.24198/jkip.v6i2.15440.

Sanyoto, Ebdi Sadjiman. "Metode Perancangan Komunikasi Visual Periklanan. Yogyakarta." Dimensi Press, 2006.

Saptodewo, Febrianto. "Desain Infografis Sebagai Penyajian Data Menarik." Jurnal Desain, vol. 1, no. 03, 2014, pp. 193-198, https://journal.Ippmunindra.ac.id/index.php/Jurnal Desain/article/view/563.

Soekmono, Roden. Pengantar Sejarah Kebudayaan Indonesia 2. Kanisius, 1973.

Tinarbuko, Isidorus Tyas Sumbo. Dekave: Desain Komunikasi Visual Penanda Zaman Masyarakat Global. CAPS, 2015. 